\title{
Oxidative stress affects responsiveness to hypotonicity of renal cells
}

\author{
Rossana Morabito, ${ }^{1}$ Giuseppa La Spada, ${ }^{2}$ Silvia Dossena, ${ }^{3}$ Angela Marino ${ }^{2}$ \\ ${ }^{1}$ Department of Human and Social Sciences, University of Messina; ${ }^{2}$ Department of Biological and \\ Environmental Sciences, University of Messina, Italy; ${ }^{3}$ Institute of Pharmacology and Toxicology, \\ Paracelsus Medizinische Privatuniversität, Salzburg, Austria
}

\begin{abstract}
Oxidative stress plays a critical role in the pathophysiology of several kidney diseases and is the consequence of alterations like ischemic events. The regulatory volume decrease (RVD) is an homeostatic response essential to many cells, including renal cells, to counteract changes in the osmolarity of the external medium. The aim of the present work is to verify whether oxidative stress affects RVD in a model of renal cells (human embryonic kidney cells, HEK 293 Phoenix). To accomplish this aim, the experimental procedure consisted in: i) cell culture preparation and treatment with $200 \mu \mathrm{M} \mathrm{H}_{2} \mathrm{O}_{2}$; and ii) measurement of cell volume changes in isotonic conditions or following hypotonic stress. $\mathrm{H}_{2} \mathrm{O}_{2}$ added to the extracellular isotonic solution induced a significant reduction in cell volume, and added to the extracellular hypotonic solution dramatically impaired the expected osmotic cell swelling. Pre-incubation of cells in an extracellular isotonic solution containing $\mathrm{H}_{2} \mathrm{O}_{2}$ prevented cell from swelling after hypotonic stress application. In conclusion, $\mathrm{H}_{2} \mathrm{O}_{2}$ leads to cell shrinkage in isotonic conditions, inhibits the hypotonicity-induced cell swelling and consequently prevents RVD, hypothetically due to an activation of
\end{abstract}

Correspondence: Angela Marino, Department of Human and Social Sciences, University of Messina, viale Ferdinando Stagno D’Alcontres 31, 98166 Messina, Italy.

Tel.: +39.090 .6765214 - Fax: +39.090 .394030 .

E-mail: marinoa@unime.it

Key words: cell volume regulation, RVD, oxidative stress, kidney cells.

Contributions: RM, AM, SD, data collecting and analyzing; AM, manuscript writing and reviewing, references search; SD, manuscript reviewing; GL, manuscript reviewing and references search.

Conflict of interests: the authors declare no potential conflict of interests.

Received for publication: 30 October 2014.

Revision received: 17 November 2014.

Accepted for publication: 18 November 2014.

CCopyright R. Morabito et al., 2014

Licensee PAGEPress, Italy

Journal of Biological Research 2014; 87:4811

doi:10.4081/jbr.2014.4811

This article is distributed under the terms of the Creative Commons Attribution Noncommercial License (by-nc 3.0) which permits any noncommercial use, distribution, and reproduction in any medium, provided the original author(s) and source are credited. transport pathways determining ion loss and, in turn, water efflux. Cell shrinkage in isotonic conditions is a hallmark of apoptosis and is known as the apoptotic volume decrease.

\section{Introduction}

Kidney plays a major role in the control of salt and water homeostasis in all mammals, and hence determines the extracellular volume and solute composition of the organism. Alterations in water and ion fluxes at the level of the kidney may be often associated with diseases, like the hereditary disorders nephrogenic diabetes insipidus and Liddle's syndrome., ${ }^{1,2}$ Renal tubule cells are continuously exposed to hyposmotic and hyperosmotic conditions during the process of urine production, therefore, adaptive mechanisms to regulate the cellular volume are critical to maintain their viability and functionality. 3,4

As a general feature, cell volume homeostasis is common to all animals and plants and can be influenced by different physiological and pathological factors including diet and environment. ${ }^{3,5-7}$ Trans-membrane water movement follows the osmotic gradient and may be achieved by simple diffusion through the lipid bilayer or through water channels, referred to as aquaporins (AQPs), ${ }^{8,9}$ or both. Osmotically driven water movement, along with ion fluxes, underlies the physiological mechanisms regulating volume and fluid homeostasis in most cells. ${ }^{410}$

Volume regulation under anisosmotic conditions is essential to cell survival and counteracts changes in the osmolarity of the extracellular medium. In particular, when exposed to a hyposmotic medium, cells undergo to osmotic swelling, known as osmotic phase (OP). Cell swelling can disrupt the cell membrane if not opportunely counterbalanced. Depending on the species and cell type, cell volume returns either immediately or slowly to control values because of the adaptive mechanism of the regulatory volume decrease (RVD). This homeostatic response has been mostly investigated in mammalian cells such as astrocytes, ${ }^{11}$ erythrocytes from different sources,${ }^{12}$ lymphocytes ${ }^{13}$ and sperm, ${ }^{14}$ but also in cells of lower vertebrates and invertebrates. ${ }^{15-18}$

The series of events leading to RVD has been at least partially defined and consists in loss of intracellular osmolytes followed by a concomitant rapid efflux of intracellular water. Thus, the pivotal counterparts of RVD are: i) ion conducting pathways, mainly permeable to $\mathrm{K}^{+}, \mathrm{Cl}^{-}$and organic anions, allowing for the flux of osmolytes out of the cell; and ii) water transporting proteins (AQPs), allowing for the efflux of water along the osmotic gradient. ${ }^{4,19,20}$

Oxidative stress has a critical role in the pathophysiology of several kidney diseases. Several systemic diseases such as hypertension and diabetes mellitus, environmental and occupational chemicals, smoking, as well as alcohol consumption induce renal oxidative stress. ${ }^{21}$ Oxidative stress also occurs during ischemia/reperfusion (I/R) injury. ${ }^{22}$

Since the kidney is an organ highly vulnerable to damage caused by oxidative stress and adaptive mechanisms to face changes in the 
osmolarity of the extracellular medium are critical for viability and function of renal cells, ${ }^{20}$ we investigated if the oxidative stress may alter the RVD response. To this aim, the time course of cell volume changes in HEK 293 Phoenix cells has been monitored isotonic and hypotonic solutions in the presence or absence of $200 \mu \mathrm{M} \mathrm{H}_{2} \mathrm{O}_{2}$.

\section{Materials and Methods}

Human renal HEK 293 Phoenix cells ${ }^{23}$ were cultured in minimum essential eagle medium [(MEM); Sigma Aldrich, St. Louis, MO, USA] supplemented with 10\% fetal bovine serum [(FBS); Cambrex Bio Science, East Rutherford, NJ, USA], $2 \mathrm{mM}$ l-glutamine, $100 \mu \mathrm{g} / \mathrm{mL}$ streptomycin, $100 \mathrm{U} / \mathrm{mL}$ penicillin and $1 \mathrm{mM}$ pyruvic acid (sodium salt). The cells were maintained at $37^{\circ} \mathrm{C}, 5 \% \mathrm{CO}_{2}, 95 \%$ air and $100 \%$ humidity. Subcultures were routinely established every second to third day by seeding the cells into $100 \mathrm{~mm}$ diameter Petri dishes following trypsin/ethylene diamine tetraacetic acid treatment.

\section{Regulatory volume decrease tests}

To perform RVD tests, HEK 293 Phoenix cells were grown on $18 \times 18$ mm coverslips successively placed upside down on a glass slide. A make-shift perfusion chamber was assembled by placing double sided tape between the glass slide and the coverslip with cells. The extracellular medium was completely and rapidly exchanged by adding either an isosmotic or hyposmotic solution to one side of the coverslip and removing it at the opposite side with strips of filter paper, according to the experimental plans described below.

\section{Control tests}

With regard to control RVD tests, cells were exposed to: $1^{\text {st }}$ step, isosmotic solution for $5 \mathrm{~min}$; $2^{\text {nd }}$ step, hyposmotic solution $(\sim 15 \%$ reduction of osmolality) for $30 \mathrm{~min}$; $3^{\text {rd }}$ step, isosmotic solution for $5 \mathrm{~min}$. In addition, volume of cells was monitored in isosmotic solution for $30 \mathrm{~min}$.

\section{$\mathrm{H}_{2} \mathrm{O}_{2}$ treatment}

With regard to the RVD tests in $200 \mu \mathrm{M} \mathrm{H}_{2} \mathrm{O}_{2}$-containing medium, the following experimental protocols were used: i) $1^{\text {st }}$ step, isosmotic solution with or without $200 \mu \mathrm{M} \mathrm{H}_{2} \mathrm{O}_{2}$ for $30 \mathrm{~min} ; 2^{\text {nd }}$ step, hyposmotic solution for $15 \mathrm{~min}$; ii) $1^{\text {st }}$ step, isosmotic solution for $5 \mathrm{~min}$; $2^{\text {nd }}$ step, hyposmotic solution with or without $200 \mu \mathrm{M} \mathrm{H}_{2} \mathrm{O}_{2}$ for $30 \mathrm{~min} ; 3^{\text {rd }}$ step, isosmotic solution for $5 \mathrm{~min}$.

In addition, volume of cells was monitored in isosmotic solution with or without $200 \mu \mathrm{M} \mathrm{H}_{2} \mathrm{O}_{2}$ for $30 \mathrm{~min}$. Cell volume measurements were taken from cells demonstrating strong adhesion to the coverslip after checking with a microscope (Leica DMLS, 400× magnification; Leica Microsystems $\mathrm{GmbH}$, Wetzlar, Germany) during continuous perfusion. For each experiment, about 30 images/cell (1 image/min) were recorded with a phase contrast microscope (Leica DMLS, $400 \times$ magnification; Leica Microsystems $\mathrm{GmbH}$ ) connected to a video camera (Digital CCD camera) and a computer equipped with suitable software (Movie Maker; Microsoft Co., Redmond, WA, USA). Cell diameter was measured for each recorded image and, assuming the cell as a sphere, cell volume was successively calculated and expressed as $V / N_{0}$, where $V_{0}$ was the initial volume in isotonic solution.

\section{Experimental solutions and reagents}

Isotonic solution: $\mathrm{MgCl}_{2}, 2.5 \mathrm{mM} ; \mathrm{CaCl}_{2}, 2.5 \mathrm{mM} ; \mathrm{HEPES}, 10 \mathrm{mM} ; \mathrm{NaCl}$, $125 \mathrm{mM}$; mannitol, $50 \mathrm{mM}$; pH 7.4; osmotic pressure $314.33 \mathrm{m0sm} / \mathrm{kg}_{\mathrm{H} 2 \mathrm{O}}$. Hyposmotic solution ( $15 \%$ reduction of osmolality): $\mathrm{MgCl}_{2}, 2.5 \mathrm{mM}$; $\mathrm{CaCl}_{2}, 2.5 \mathrm{mM}$; HEPES, $10 \mathrm{mM}$; NaCl, $125 \mathrm{mM}$; pH 7.4; osmotic pressure
$263 \mathrm{m0sm} / \mathrm{kg}_{\mathrm{H} 20}$. $\mathrm{pH}$ measurements were taken with an Orion $\mathrm{pH}-m e t e r$ and osmolality was measured by a Fiske osmometer.

\section{Statistics}

Data are shown as mean values \pm standard error of the mean. Each data set is derived from five individual experiments. Significance of the differences between data was tested using one- or two-way analysis of variance (ANOVA), followed by Dunnet's or Bonferroni's post-hoc test, as appropriated. $\mathrm{P}<0.05$ was considered as statistically significant.

\section{Results}

\section{Control tests}

Cells were bathed in isotonic solution for 5 min ( $1^{\text {st }}$ step; Figure 1A) and then exposed to an extracellular hypotonic solution for $30 \mathrm{~min}\left(2^{\text {nd }}\right.$ step; Figure 1A). Upon hyposmotic shock, an increase in the cell $V / \mathrm{V}_{0}$ ratio was observed, indicating a substantial cell swelling corresponding to $\mathrm{OP}$. V/ $\mathrm{N}_{0}$ reached a peak value of $1.294 \pm 0.025$ within $5 \mathrm{~min}$, a value significantly higher than the one observed in isotonic solution $(\mathrm{P}<0.001)$. After the $0 \mathrm{P}$, the $\mathrm{V} / \mathrm{N}_{0}$ ratio gradually fell to $1.031 \pm 0.016$, a

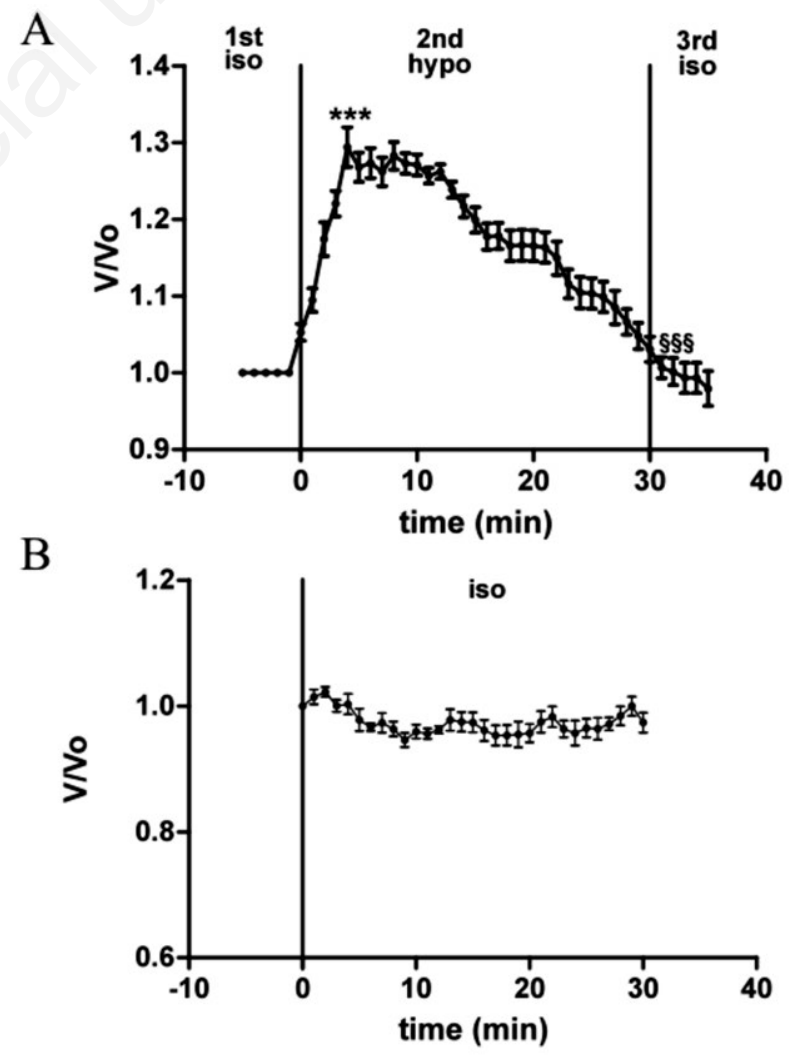

Figure 1. Cells bathed in isotonic solution. A) Cell volume $\left(\mathrm{V} / \mathrm{V}_{0}\right)$ measured as a function of time after exposure of cells to isosmotic $\left(1^{\text {st }}\right.$ and $3^{\text {rd }}$ step) and hyposmotic ( $2^{\text {nd }}$ step) solution. The peak $V / V_{0}$ value in hypotonic solution was significantly higher than that measured in isosmotic solution $\left({ }^{* * *} \mathrm{P}<0.001\right)$. At the end of the $2^{\text {nd }}$ step $V / V_{0}$ was significantly different from the peak value $(\$ \$ \$ P<0.001)$. B) $V / V_{0}$ determined during a 30 min observation in isosmotic condition. No significant volume changes were observed. 
value significantly lower respect to the peak value $(\mathrm{P}<0.001)$, corresponding to the RVD phase. After returning to the isosmotic medium ( $3^{\text {rd }}$ step), cell volume was comparable to the one observed during the $1^{\text {st }}$ step $(0.979 \pm 0.022)$, without a post-RVD regulatory volume increase (RVI). Post-RVD RVI has not been seen in these experiments, probably because of the short time of observation after the replacement of the hyposmotic medium with the isosmotic one.

In addition, cells were maintained in isotonic solution for $30 \mathrm{~min}$ and their volume was monitored (Figure 1B). At the beginning of the incubation is isotonic solution $V / N_{0}$ was $1 \pm 0.025$, with no significant changes during the whole experiment.

\section{$\mathrm{H}_{2} \mathrm{O}_{2}$ treatment}

The exposure of cells to $200 \mu \mathrm{M} \mathrm{H}_{2} \mathrm{O}_{2}$ in isotonic solution (Figure 2) induced a gradual and significant decrease in $\mathrm{V}_{0}$, starting after 10 min of treatment. $V / N_{0}$ reached a value of $0.656 \pm 0.023$ after 30 min. This value was significantly lower respect to that observed in untreated cells $(\mathrm{P}<0.001)$.

In a further experimental protocol, cells were first bathed in isotonic solution with or without (control) $200 \mu \mathrm{M} \mathrm{H}_{2} \mathrm{O}_{2}$ (Figure $3 ; 1^{\text {st }}$ step), and then exposed to the hypotonic solution (Figure $3 ; 2^{\text {nd }}$ step). Interestingly, pre-incubation of cells in isotonic medium plus $200 \mu \mathrm{M}$ $\mathrm{H}_{2} \mathrm{O}_{2}$ prevented cell swelling, being $\mathrm{V} / \mathrm{N}_{0}$ after 5 min of hypotonic shock $(0.712 \pm 0.018)$ comparable, from one hand, to the value observed at the end of the $1^{\text {st }}$ period $(0.734 \pm 0.011)$ and, from the other hand, significantly lower than the corresponding value of untreated cells (1.290土0.011).

Treatment of cells with a hyposmotic solution containing $200 \mu \mathrm{M}$ $\mathrm{H}_{2} \mathrm{O}_{2}$ (Figure 4) significantly impaired the cell swelling normally observed during the osmotic phase. During the $2^{\text {nd }}$ step, $V / N_{0}$ reached a peak value of $1.046 \pm 0.023$, comparable to that observed in isotonic conditions ( $1^{\text {st }}$ step) and significantly lower than that of untreated cells $(1.290 \pm 0.011 ; \mathrm{P}<0.001)$. At the end of the hyposmotic challenge ( $2^{\text {nd }}$ step), $V / \mathrm{N}_{0}$ decreased to a value of $0.753 \pm 0.040$, significantly lower with respect to the peak value of both treated and untreated cells $(\mathrm{P}<0.001)$. Cell volume further decreased when the hyposmotic solution was substituted with the isotonic one $\left(\mathrm{V} / \mathrm{N}_{0}=0.645 \pm 0.053\right.$; end of the $3^{\text {rd }}$ step).

\section{Discussion}

The results obtained in the present work confirm that HEK 293 Phoenix cells, submitted to a $\sim 15 \%$ hyposmotic stress, exhibit the expected significant cell swelling within 5 min of hyposmotic shock application and progressively regulate their volume, completely restoring the initial $\mathrm{V} / \mathrm{N}_{0}$ values within $30 \mathrm{~min}$ of hyposmotic challenge (Figure 1A). Cell volume regulation in renal cells, including HEK 293 Phoenix cells, as well as in many other cell types, including those of invertebrates, has been already studied ${ }^{24,25}$ and is recognized as a homeostatic response accounting for cell viability. It is thus reasonable to consider this parameter to monitor cell function in different conditions, such as diseases, exposure to drugs, pollutants and metabolites, with their possible detrimental effects, including oxidative stress events. ${ }^{26-31}$ Amongst renal alterations, interesting is the case of renal I/R injury, which causes acute renal failure in several clinical settings like kidney transplantation. ${ }^{32,33}$ The mechanisms of renal acute injury induced by $\mathrm{I} / \mathrm{R}$ is multifactorial and involves hypoperfusion, inflammatory responses, along with free radical induced damage.

On this basis, in an attempt to give more information about the damage deriving from oxidative stress events in renal cells, the present

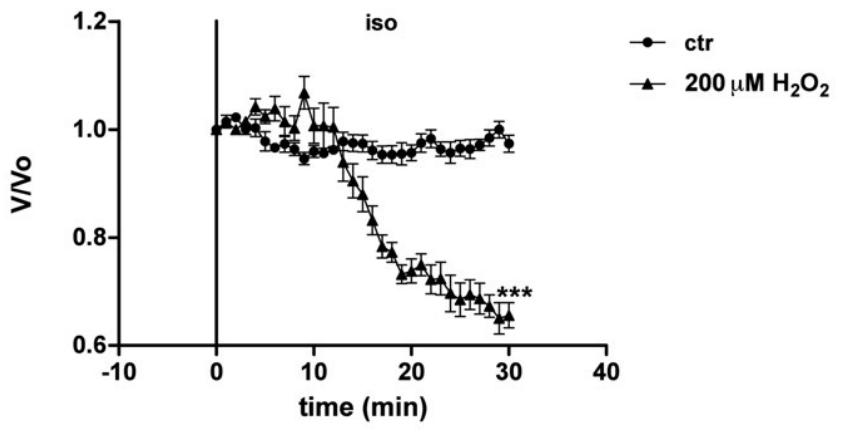

Figure 2. Volume $\left(\mathrm{V} / \mathrm{V}_{0}\right)$ of cells exposed to an isosmotic solution containing $200 \mu \mathrm{M} \mathrm{H}_{2} \mathrm{O}_{2}$; comparison with untreated cells [control (ctr)]. Cell volume of treated cells reached a value significantly lower than that observed in control cells $(* * * P<0.001)$.

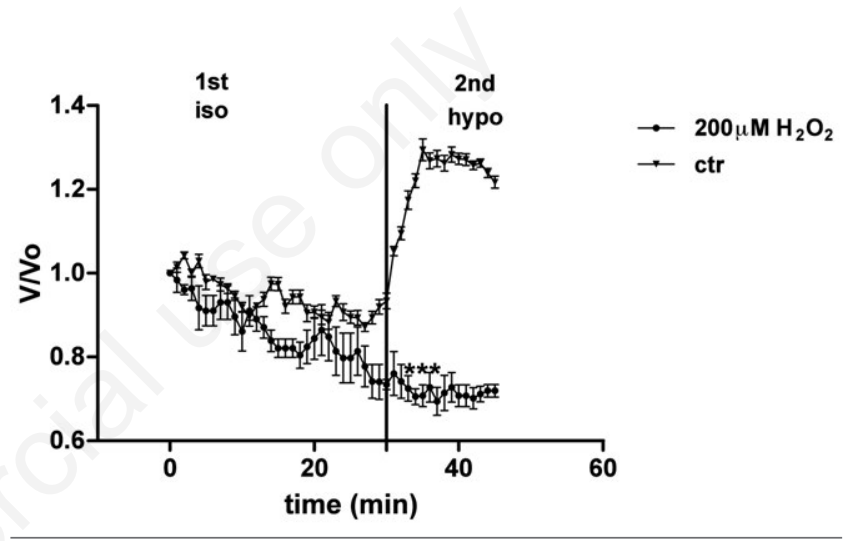

Figure 3. Volume $\left(\mathrm{V} / \mathrm{V}_{0}\right)$ of cells exposed to $200 \mu \mathrm{M} \mathrm{H} \mathrm{H}_{2} \mathrm{O}_{2}$ in isotonic medium ( $1^{\text {st }}$ step) and then submitted to a hyposmotic challenge ( $2^{\text {nd }}$ step); comparison with untreated cells [control (ctr)]. $\mathrm{H}_{2} \mathrm{O}_{2}$ was present only during the $1^{\text {st }}$ step. After $5 \mathrm{~min}$ of hypotonic stress, $\mathrm{V} / \mathrm{V}_{0}$ of treated cells was significantly lower than that observed in control cells $(* * * \mathrm{P}<\mathbf{0 . 0 0 1})$.

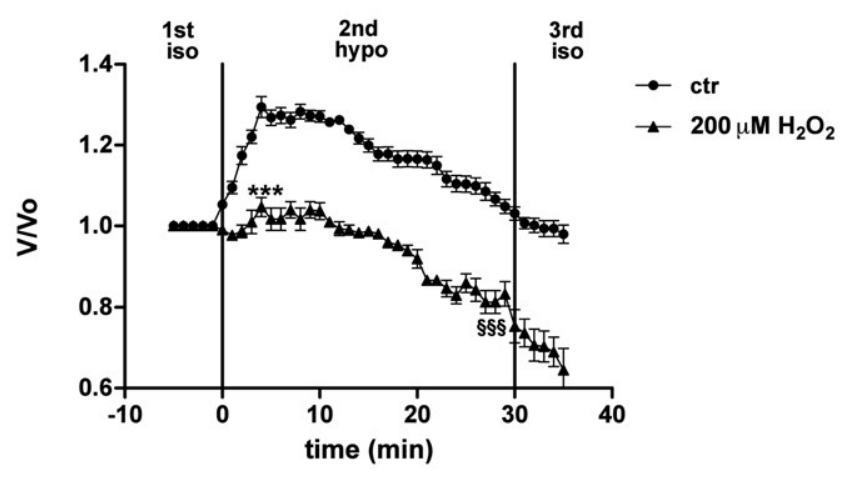

Figure 4. Volume $\left(\mathrm{V} / \mathrm{V}_{0}\right)$ of cells exposed to a hyposmotic solution containing $200 \mu \mathrm{M} \mathrm{H}_{2} \mathrm{O}_{2}$; comparison with untreated cells [control (ctr) $]. \mathrm{H}_{2} \mathrm{O}_{2}$ was added at the beginning of the $2^{\text {nd }}$ step and remained throughout. The peak $\mathrm{V} / \mathrm{V}_{0}$ value of treated cells was significantly lower than that observed for control cells $\left({ }^{* * *} \mathrm{P}<0.001\right) . \mathrm{V} / \mathrm{V}_{0}$ of treated cells at the end of the $2^{\text {nd }}$ step was significantly lower than the peak $\mathrm{V} / \mathrm{V}_{0}$ value and lower than that observed for control cells $(\$ \Phi \$ P<0.001)$. 
paper proposes HEK 293 Phoenix cells as an in vitro model to ascertain the effect of $\mathrm{H}_{2} \mathrm{O}_{2}$-induced oxidative stress on a cell response like cell volume regulation capability, with specific regard to RVD.

Our results show that the exposure of HEK 293 Phoenix cells to $\mathrm{H}_{2} \mathrm{O}_{2}$ in isotonic conditions induced, within $10 \mathrm{~min}$, a notable cell shrinkage (Figure 2), possibly as a consequence of ion and obliged water efflux. Two hundred $\mu \mathrm{M} \mathrm{H}_{2} \mathrm{O}_{2}$ was effective in altering cell morphology without inducing cell death, since cell viability was assessed after each experiment by the Trypan blue dye exclusion test (data not shown).

Moreover, a 30 min exposure of cells to an isotonic medium containing $\mathrm{H}_{2} \mathrm{O}_{2}$ determined, in addition to a significant shrinkage, the impairment of the expected cell swelling after hyposmotic challenge (Figure 3). This observation can be explained by oxidative stress events, due to $\mathrm{H}_{2} \mathrm{O}_{2}$ treatment, provoking cell shrinkage because of ion and water loss, a response associated to an initial stage of apoptosis, as reviewed by Bortner and Cidlowski. ${ }^{34}$ It is likely that the application of $15 \%$ hyposmotic shock impaired cell swelling since the intracellular ions concentration, namely $\mathrm{K}^{+}$and $\mathrm{Cl}^{-}$, was diminished under $\mathrm{H}_{2} \mathrm{O}_{2}$ treatment.

A further experimental protocol demonstrated that $\mathrm{H}_{2} \mathrm{O}_{2}$ treatment during $15 \%$ hyposmotic stress dramatically blunted the expected cell swelling and consequently prevented RVD mechanisms. In contrast, pronounced cell shrinkage occurred and was obvious at the end of the hyposmotic challenge (Figure 4).

Reduction of cell volume in isotonic conditions or cell shrinkage is considered as a hallmark of programmed cell death, a process called apoptosis. $^{34}$ This phenomenon has been termed apoptotic volume decrease (AVD) and differs from RVD occurring in anisotonic conditions. ${ }^{35}$

The signaling pathways underlying AVD modulate ion fluxes. ${ }^{35}$ In this regard, monovalent ions, like intracellular $\mathrm{K}^{+}$, seem to be specifically involved in controlling the cell death process. Blockage of loss of this ions has been in fact demonstrated to protect cells from apoptosis. ${ }^{34}$

Potassium has received considerable attention being the most abundant, osmotically relevant cation of the intracellular environment. As already stated, $\mathrm{K}^{+}$and $\mathrm{Cl}^{-}$efflux have been shown to play a major role in RVD mechanisms in many cell types, leading to obliged water efflux. $^{3,4}$ Bortner and Cidlowski (2007) in their review ${ }^{34}$ also reported about the relationship between morphological change and intracellular monovalent ions during apoptosis. According to these and other authors $^{36}$ it is reasonable to suggest that, in our model of renal cell, the oxidative stress induced by the exposure of cells to $\mathrm{H}_{2} \mathrm{O}_{2}$ elicited ion efflux and, hence, water loss in isotonic conditions and cell shrinkage as an early step in the apoptosis process. It is likely that the $\mathrm{H}_{2} \mathrm{O}_{2}$ induced cell shrinkage masked the cell swelling and the subsequent RVD normally expected after hypotonic challenge. Apoptosis has not been ascertained in the present work.

\section{Conclusions}

In conclusion, our results suggest that: i) HEK 293 Phoenix cells are a suitable model to study cell volume regulation; ii) these cells exhibit a RVD response occurring within 30 min of hyposmotic challenge; iii) oxidative stress under $\mathrm{H}_{2} \mathrm{O}_{2}$ exposure provokes cell shrinkage in isotonicity and unresponsiveness to hyposmotic challenge, probably due to ion and water loss. These observations suggest that ion channels, involved in RVD and playing a role in triggering AVD and apoptosis, may be considered as a possible target for therapeutic strategies to counteract organ and tissue damage deriving from oxidative stress and subsequent apoptotic events, as in the case of $I / R$ injury. Moreover, a precise window of time for a possible modulation of ion fluxes affected by oxidative stress could also be defined.

\section{References}

1. Bubien JK. Epithelial Na+ channel (ENaC), hormones, and hypertension. J Biol Chem 2010;285:23527-23531.

2. Karet FE. Disorders of water and acid-base homeostasis. Nephron Physiol 2011;118:28.

3. Lang F, Volky H, Paulmichl M. How do cells regulate their volume. Pflug Arch Ges Phys 1998;411:4-5.

4. Hoffman EK, Lambert IH, Pedersen SF. Physiology of cell volume regulation in vertebrates. Physiol Rev 2009;89:193-277.

5. Boge G, Roche H. In vitro effects of wastewater treatment plant effluent on sea bass red blood cells. Comp Biochem Phys C 2004;139:17-22.

6. Schmidt-Nielsen B. Comparative physiology of cellular ion and volume regulation. J Exp Zool 1975;194:207-19.

7. Chara 0, Espelt MV, Krumschnabel G, Schwarzbaum PJ. Regulatory volume decrease and $\mathrm{P}$ receptor signaling in fish cells: mechanisms, physiology, and modeling approaches. J Exp Zool Part A 2011;315:175-202.

8. Carbrey JM, Agre P. Discovery of the aquaporins and development of the field. Handb Exp Pharmacol 2009;190:3-28.

9. Ishibashi K, Kondo S, Hara S, Morishita Y. The evolutionary aspects of aquaporin family. Am J Physiol Reg-I 2011;300:566-76.

10. Heymann JB, Engel A. Aquaporins: phylogeny, structure, and physiology of water channels. News Physiol Sci 1999;14:187-93.

11. Aschner M. Volume measurements in cultured primary astrocytes. Methods Mol Biol 2011;758:391-402.

12. Wormser C, Pore SA, Elperin AB, et al. Potentiation of regulatory volume decrease by a $\mathrm{p} 2$ - like receptor and arachidonic acid in American alligator erythrocytes. J Membrane Biol 2011;242:75-87.

13. Bobak N, Bittner S, Andronic J, et al. Volume regulation of murine $\mathrm{T}$ lymphocytes relies on voltage-dependent and two-pore domain potassium channels. Biochem Biophys Acta 2011;1808:2036-44.

14. Chen Q, Duan EK. Aquaporins in sperm osmoadaptation: an emerging role for volume regulation. Acta Pharmacol Sin 2011;32:721-4.

15. Marino A, Morabito R, La Spada G, et al. Mechanisms of hyposmotic volume regulation in isolated nematocytes of the anthozoan Aiptasia diaphana. Cell Physiol Biochem 2010;26:209-18.

16. Marino A, Morabito R, La Spada G, et al. Evidence for aquaporinmediated water transport in nematocytes of the jellyfish Pelagia noctiluca. Cell Physiol Biochem 2011;28:1211-8.

17. Morabito R, Marino A, La Spada G. Heavy metals affect regulatory volume decrease (RVD) in nematocytes isolated from the jellyfish Pelagia noctiluca. Comp Biochem Phys A 2013;165:199-206.

18. Morabito R, Marino A, Lauf PK, et al. Sea water acidification affects osmotic swelling, regulatory volume decrease and discharge in nematocytes of the jellyfish Pelagia noctiluca. Cell Physiol Biochem 2013;32:77-85.

19. Strange K. Cellular volume homeostasis. Adv Physiol Educ 2004;28:155.

20. Zarogiannis SG, Ilyaskin AV, Baturina GS, et al. Regulatory volume decrease of rat kidney principal cells after successive hypo-osmotic shocks. Math Biosci 2013;244:176-87.

21. Ozbek E. Induction of oxidative stress in kidney. Int $\mathrm{J}$ Nephrol 2012;2012:465897.

22. Aragno M, Cutrin JC, Mastrocola R, et al. Oxidative stress and kidney dysfunction due to ischemia/reperfusion in rat: attenuation by dehydroepiandrosterone. Kidney Int 2003;64:836-43.

23. Di Ciommo DP, Duckett A, Burcescu I, et al. Retinoblastoma protein purification and transduction of retina and retinoblastoma cells using improved alphavirus vectors. Invest Ophth Vis Sci 2004;45:3320-9. 
24. Kössler S, Nofziger C, Jakab M, et al. Curcumin affects cell survival and cell volume regulation in human renal and intestinal cells. Toxicology 2012;292:123-35.

25 Dossena S, Gandini R, Tamma G, et al. The molecular and functional interaction between ICln and HSPC038 proteins modulates the regulation of cell volume. J Biol Chem 2011;286:40659-70.

26. Marino A, Di Paola R, Crisafulli C, et al. Protective effect of melatonin against the inflammatory response elicited by crude venom from isolated nematocysts of Pelagia noctiluca (Cnidaria, Scyphozoa). J Pineal Res 2009;47:56-69.

27. Morabito R, Condello S, Currò M, et al. Oxidative stress induced by crude venom from the jellyfish Pelagia noctiluca in neuronal-like differentiated SH-SY5Y cells. Toxicol in Vitro 2012;26:694-9.

28. Morabito R, Marino A, Romano P, et al. Sulphate and chloridedependent potassium transport in human erythrocytes are affected by crude venom from nematocysts of the jellyfish Pelagia noctiluca. Cell Physiol Biochem 2013;32:86-95.

29. Bruschetta G, Impellizzeri D, Morabito R, et al. Pelagia noctiluca (Scyphozoa) crude venom injection elicits oxidative stress and inflammatory response in rats. Mar Drugs 2014;12:2182-204.

30. Morabito R, Marino A, Dossena S, La Spada G. Nematocyst discharge in Pelagia noctiluca (Cnidaria, Scyphozoa) oral arms can be affected by lidocaine, ethanol, ammonia and acetic acid. Toxicon 2014;83:52-8.

31. Morabito R, Dossena S, La Spada G, Marino A. Heavy metals affect nematocysts discharge response and biological activity of crude venom in the jellyfish Pelagia noctiluca (Cnidaria, Scyphozoa). Cell Physiol Biochem 2014;34:244-54.

32. Perco P, Pleban C, Kainz A, et al. Gene expression and biomarkers in renal transplant ischemia reperfusion injury. Transplant Int 2007;20:2-11.

33. Di Paola R, Genovese T, Impellizzeri D, et al. The renal injury and inflammation caused by ischemia-reperfusion are reduced by genetic inhibition of TNF- R1: a comparison with infliximab treatment. Eur J Pharmacol 2013;700:134-46.

34. Bortner CD, Cidlowski JA. Cell shrinkage and monovalent cation fluxes: role in apoptosis. Arch Biochem Biophys 2007;462:176-88.

35. Okada Y, Maeno E. Apoptosis, cell volume regulation and volume-regulatory chloride channels. Comp Biochem Phys A 2001;130:377-83.

36. Lambert IH, Klausen TK, Bergdahl A, et al. ROS activated KCl cotransport in nonadherent Ehrlich ascites cells but $\mathrm{K}^{+}$and $\mathrm{Cl}^{-}$ channels in adherent Ehrlich Lettrè and NIH3T3 cells. Am J Physiol-Cell Ph 2009;297:198-206. 